\title{
MOLECULAR SYSTEMATICS OF TELIPOGON (ORCHIDACEAE: ONCIDIINAE) AND ITS ALLIES: NUCLEAR AND PLASTID DNA SEQUENCE DATA
}

\author{
Norris H. Williams ${ }^{1,3}$, W. Mark Whitten ${ }^{1}$, and Robert L. Dressler ${ }^{1,2}$ \\ ${ }^{1}$ Florida Museum of Natural History, University of Florida, Gainesville, FL 32611, USA \\ ${ }^{2}$ Jardín Botánico Lankester, Universidad de Costa Rica, apdo. 1031-7050, Cartago, Costa Rica \\ ${ }^{3}$ Author for correspondence: orchid@flmnh.ufl.edu
}

\begin{abstract}
Phylogenetic relationships of Telipogon Kunth, Ornithocephalus Hook. and related genera (Orchidaceae: Oncidiinae) were evaluated using parsimony analyses of data from the internal transcribed spacers of nuclear ribosomal (nrITS DNA) and three plastid regions (matK, trnL-F, and the atpB-rbcL intergenic spacer region). In addition to an analysis of 81 OTU's for ITS only, we used a matrix of 30 taxa for combined nuclear and plastid analyses. Stellilabium is embedded within Telipogon and should be merged with the latter genus. Telipogon consists of two South American clades and a Central American clade. One Stellilabium clade is sister to the Central American clade of Telipogon, and the second Stellilabium clade is sister to all of the Central American species of Telipogon and Stellilabium. Hofmeisterella is a member of the Telipogon alliance. The genus Dipterostele is not supported by this work. Nomenclatural changes are made transferring Stellilabium to Telipogon.
\end{abstract}

\begin{abstract}
RESUMEN. Se evaluaron las relaciones filogenéticas de Telipogon, Ornithocephalus y géneros afines (Orchidaceae: Oncidiinae) mediante análisis de parsimonia de datos de espaciadores de ADN ribosomal nuclear (nrITS) y de tres regiones de $\mathrm{ADN}$ de plastidios ( $m a t K, \operatorname{trn} L-F$ y la región espaciadora intergénica $a t p B-r b c L$ ). Además de un análisis de 81 OTU con ITS, se usó una matriz de 30 taxa para realizar análisis combinados de ADN nuclear y de plastidios. Stellilabium aparece anidado dentro de Telipogon. Éste presenta dos clados sudamericanos y uno centroamericano. Un clado de Stellilabium es hermano del clado centroamericano de Telipogon; el segundo clado de Stellilabium es hermano de todas las especies centroamericanas de Telipogon y Stellilabium. Hofmeisterella es un miembro del grupo de Telipogon. El género Dipterostele como tal no se justifica, según este estudio. Se realizan cambios nomenclatoriales para transferir las especies de Stellilabium a Telipogon.
\end{abstract}

Key words / Palabras Clave: Hofmeisterella, Ornithocephalus, Stellilabium, Telipogon, Oncidiinae, Orchidaceae

The phylogenetic placements of Telipogon Kunth and its relatives (formerly in subtribe Telipogoninae), Ornithocephalus Hook. and its relatives (formerly in subtribe Ornithocephalinae), Pachyphyllum Kunth and Fernandezia Ruiz \& Pav. (formerly in subtribe Pachyphyllinae), and Lockhartia Hook. (formerly in subtribe Lockhartiinae) have been unclear for many years, although most authors now agree that these taxa belong in Maxillarieae (Dressler 1993) and are related to subtribe Oncidiinae (sensu Dressler 1993). Telipogoninae and Ornithocephalinae have been separated from Oncidiinae on the basis of four pollinia versus two in the Oncidiinae. Dressler (1993) included Pachyphyllum, Fernandezia, and Lockhartia in the Oncidiinae. Our earlier analyses (Whitten et al. 2000) showed that these groups all belong within the Oncidiinae, and we later reported on 10 species in these alliances, which we analyzed using a combined matrix of ITS/matk/trnL-F for a total of 79 species (Williams et al. 2001a). The species studied here represent a broad sampling of species from both Central America (primarily Panama and Costa Rica) and northern South America (primarily Ecuador).

The relationships of the Telipogon - Pachyphyllum - Ornithocephalus alliances were demonstrated in our earlier study, but the systematic position of Lockhartia was not satisfactorily resolved at that time (Williams et al. 2001a,b). The Telipogon - Pachyphyllum Ornithocephalus alliances are sister groups embedded within the Oncidiinae. In those studies Lockhartia was an isolated group within the Oncidiinae, but the threegene analysis did not resolve its closest relatives. Here we expand on that study, discuss the Telipogon alliance in more detail, and present some preliminary data on the Ornithocephalus alliance. Our larger analyses of the Oncidiinae (634 species for ITS, 252 species for 
ITS/matK/trnL-F) show that Lockhartia is sister to the Telipogon - Pachyphyllum - Ornithocephalus alliance (Williams \& Whitten 2003, and unpublished in prep.).

The systematic position of Hofmeisterella Rchb.f. has been disputed in the past. Szlachetko (1995) placed Hofmeisterella with Chytroglossa, Eloyella, Hintonella, and Phymatidium in subtribe Hintonellinae of his tribe Ornithocephaleae, whereas Dressler (1993) placed Hofmeisterella with Telipogoninae, and Dodson (pers. comm.) also considered inclusion within Telipogoninae. We address this question by analyzing a range of species in both alliances.

\section{MATERIALS AND METHODS}

Specimens - Table 1 list taxa examined, vouchers, and GenBank numbers for all sequences. Samples for DNA extraction were taken from wild collected plants, cultivated plants, or from herbarium material.

Molecular techniques - DNA extraction, purification, PCR amplifications, sequencing, alignments, primers, etc. were the same as in Williams et al. (2001a), except as described below. All data matrices are available upon request from NHW (orchid@flmnh. ufl.edu).

The PCR protocol for the atpB-rbcL intergenic spacer was $94{ }^{\circ} \mathrm{C}$ for $2 \mathrm{~min}, 94{ }^{\circ} \mathrm{C}$ for $45 \mathrm{sec}, 62^{\circ} \mathrm{C} 1$ min, $72{ }^{\circ} \mathrm{C}$ for $75 \mathrm{sec}, 32$ cycles, and a final extension of $72^{\circ} \mathrm{C} 2 \mathrm{~min}$. The primer sequences used are given in Table 2. The original atpB-rbcL intergenic spacer primers used for this group were those of Chiang et al. (1998), but later modified as shown in Table 2.

Data matrices - Two data matrices were used: 1) an 81-OTU matrix was analyzed for ITS alone which included ITS 1 and ITS 2, the included 5.8S region, and portions of the flanking $18 \mathrm{~s}$ and $26 \mathrm{~s}$ regions; and 2) a 30-taxon subset of that matrix was used for both ITS analyses and individual and combined analyses of $m a t K, \operatorname{trn} L-F$, and the $a t p B-r b c L$ intergenic spacer. We were unable to obtain useable sequence data for Phymatidium for the trnL-F study and for Telipogon ariasii for the atpB-rbcL intergenic spacer region, so those two matrices contain only 29 taxa.

Outgroup choice - Outgroup choice was determined by our analyses of Oncidiinae (Williams et al. 2001a, b, Williams \& Whitten 2003) and by our expanded analysis of 634 taxa for ITS alone and 252 taxa for ITS/matK/trnL-F. We used Lockhartia as the outgroup in the large ITS only matrix and Fernandezia tica and Pachyphyllum sp. as the outgroup in the combined nuclear and plastid analyses.

Data analysis - PAUP* 4.0b10 (Swofford 2000) was used on a PowerMac G4 computer for all analyses with the following search strategies under Fitch parsimony (unordered characters, equal weight to all changes, Fitch 1971): 1000 replicates random taxon entry, MULTREES on, and SPR swapping holding only 10 trees/replicate to reduce time spent in swapping on large numbers of trees in each replicate. After completing the random replicates, all shortest trees found were then used as the starting trees in a search with a limit of 10000 trees with swapping to completion on these trees. Tree statistics for the analyses are given in Table 3. We performed the following analyses: individual analyses of 30 taxa for ITS, $m a t K$, $\operatorname{trn} L-F$, and the $a t p B-r b c L$ intergenic spacer; a combination of the three plastid regions; a combined ITS + plastid dataset; and an individual analysis for the 81 OTU ITS only matrix. Support was determined by bootstrap analysis performed in PAUP* and by Bayesian analysis performed in MrBayes 3.0B (Huelsenbeck \& Ronquist 2001) on the combined plastid + ITS matrix. The parameters for the Bayesian analysis were as follows: 1set $n s t=2$ rates $=$ equal; set autoclose=yes; mcmcp ngen $=2,000,000$ printfreq $=100$ samplefreq $=10$ nchains $=4$ savebrlens $=y e s ; \quad m c m c ;$ sumt; burnin $=200,000$ contype $=$ halfcompat. The analysis was repeated with rates $=$ gamma. In each case the first 10000 trees were omitted and the majority rule consensus tree obtained in PAUP* from the remaining trees. The two Bayesian analyses yielded the same topologies, identical to those of parsimony analyses.

\section{RESULTS}

Analysis of individual matrices-ITS - The ITS analysis included 795 characters, of which 375 were variable and $301(38 \%)$ potentially parsimony informative, resulting in eight trees of 914 steps $[\mathrm{CI}=0.58 \quad(0.54$ with uninformative characters excluded), $\mathrm{RI}=0.79]$. Figure 1 is one tree with branch lengths and bootstrap support (BS).

Telipogon alliance: The ITS analysis of a moderately supported (75\%BS) Telipogon alliance has a basal polytomy with Hofmeisterella, the Trichoceros clade $(100 \% \mathrm{BS})$, the Telipogon ariasii-pulcherdalstromii clade (100\%BS), and the strongly supported remainder of the group with $100 \% \mathrm{BS}$. This latter branch comprises the Telipogon nervosus-vargasii clade $(100 \% \mathrm{BS})$, sister to a weakly supported clade (74\%BS) of South American Stellilabium (100\%BS) + a weakly supported (78\%BS) clade of Central American Stellilabium (100\%BS) + Central American Telipogon (98\%BS). Within the Central American Telipogon clade, T. butcheri is sister to a strongly 
supported $(100 \% \mathrm{BS})$ clade of five additional species from Central America.

Ornithocephalus alliance: Within the strongly supported Ornithocephalus alliance (99\%BS), Phymatidium is sister to a moderately supported clade (84\%BS) consisting of two clades each with $100 \%$ BS support: one clade of Zygostates alleniana + Dipteranthus grandiflorus and a second clade of Eloyella sister to a weakly supported (59\%BS) clade of Hintonella sister to a $100 \% \mathrm{BS}$ clade of Ornithocephalus inflexus + Sphyrastylis dalstromii.

Analysis of individual matrices - $\boldsymbol{t r n} \boldsymbol{L}-\boldsymbol{F}$ - This analysis had 1252 characters, 298 were variable and $149(12 \%)$ were potentially parsimony informative, and yielded 1458 trees with a length of 425 steps [ $\mathrm{CI}=0.80$ (0.68 with uninformative characters excluded), $\mathrm{RI}=0.84]$. Figure 2 is one tree with branch lengths and bootstrap values.

Telipogon alliance: The trnL-F only analysis shows a strongly supported (93\%BS) Telipogon alliance with a weakly supported $(68 \% \mathrm{BS})$ clade of Hofmeisterella and Trichoceros sister to the strongly supported (94\%BS) remaining ingroup. The ingroup consists of a strongly supported (100\%BS) Telipogon ariasiipulcher-dalstromiii clade and a weakly supported clade (56\%BS) comprising a strongly supported $(100 \% \mathrm{BS})$ South American Stellilabium clade of three species sister to a weakly supported $(50 \% \mathrm{BS})$ clade consisting of a strongly supported (100\%BS) Telipogon nervosusvargasii clade, and a moderately supported $(76 \% \mathrm{BS})$ Central American clade which consists of a strongly supported $(97 \%$ BS) Stellilabium clade of four species and a strongly supported (99\%BS) Telipogon clade of six species. In this analysis T. butcheri is within the clade of the other Central American species of Telipogon.

Ornithocephalus alliance: The trnL-F analysis produced a strongly supported (100\%BS) Ornithocephalus alliance consisting of two clades: a strongly supported clade of $(96 \% \mathrm{BS})$ Zygostates alleniana + Dipteranthus grandiflorus and a moderately supported (77\%BS) clade of Eloyella sister to a weakly supported (59\%BS) clade of Ornithocephalus inflexus + Sphyrastylis dalstromii + Hintonella mexicana.

Analysis of individual matrices-matK - The individual mat $K$ analysis consisted of 1331 included characters, 284 were variable and 151 (11\%) were potentially parsimony informative, and yielded four trees of 434 steps [CI $=0.76$ ( 0.64 with uninformative characters excluded), $\mathrm{RI}=0.83]$. Figure 3 is one tree with branch lengths and bootstrap values.

Telipogon alliance: In this analysis the Telipogon alliance is weakly supported (62\%BS) with Hofmeisterella sister to a weakly supported (53\%BS) remainder of the alliance. The strongly supported $(100 \% \mathrm{BS})$ Trichoceros clade is sister to the moderately supported $(88 \% \mathrm{BS})$ remainder of the alliance. The remainder of the alliance consists of a strongly supported $(100 \% \mathrm{BS})$ Telipogon ariasii-pulcher-dalstromii clade + a strongly supported (99\%BS) clade consisting of a weakly supported (66\%BS) South American clade of three species of Stellilabium with $100 \%$ BS support sister to a strongly supported (99\%BS) Telipogon nervosus-vargasii clade. The Central American clade with $83 \%$ BS support consists of a strongly supported (100\%BS) clade of four species of Central American Stellilabium and the strongly supported $(100 \% \mathrm{BS})$ clade of six species of Central American Telipogon. In this analysis, as in the trnL-F analysis, $T$. butcheri was not resolved from the other Central American species of Telipogon.

Ornithocephalus alliance: The Ornithocephalus alliance (99\%BS) consists of a trichotomy of Phymatidium + a strongly supported clade (99\%BS) of Zygostates alleniana + Dipteranthus grandiflorus and a strongly supported (98\%BS) unresolved clade of Eloyella, Hintonella and a moderately supported (84\%BS) clade of Ornithocephalus inflexus + Sphyrastylis dalstromii.

Analysis of individual matrices-atpB-rbcL intergenic spacer - The individual $a t p B-r b c L$ intergenic spacer analysis consisted of 1499 included characters, of which 530 were variable and $220(15 \%)$ were potentially phylogenetically informative $[\mathrm{CI}=0.81$ ( 0.65 with uninformative characters excluded), $\mathrm{RI}=0.75$ ], and yielded three trees of 761 steps. Figure 4 shows one tree with branch lengths above the lines and bootstrap values below the lines.

Telipogon alliance: The analysis of this intergenic spacer region yielded two clades: a weakly supported (68\%BS) Telipogon alliance and a moderately supported (88\%BS) Ornithocephalus alliance. Hofmeisterella + Trichoceros $(98 \% \mathrm{BS})$ forms a trichotomy with a weakly supported $(81 \% \mathrm{BS})$ remaining Telipogon + Stellilabium clade. This large ingroup has the following groups: a strongly supported $(100 \% \mathrm{BS})$ Telipogon pulcher-dalstromii clade sister to the weakly supported remaining species $(56 \% \mathrm{BS})$ consisting of a polytomy consisting of a strongly supported (100\%BS) South American clade of three species of Stellilabium sister to a strongly supported (100\%BS) Telipogon nervosus- 
vargasii clade; a moderately supported (65\%BS) Central American clade of four species of Stellilabium with $S$. bullpenense sister to a moderately supported (78\%BS) clade of the other three species from Central America; and a strongly supported (100\%BS) clade of the six Central American species of Telipogon. Within the Central American Telipogon clade, T. parvulus is sister to a moderately supported $(82 \% \mathrm{BS})$ clade of $T$. biolleyi-butcheri-caulescens-seibertii-panamensis, and within that clade is a weakly supported $(70 \% \mathrm{BS})$ yet unresolved polytomy of $T$. biolleyi-butchericaulescens-seibertii.

Ornithocephalus alliance: This alliance with 88 $\%$ bootstrap support consists of a strongly supported (96\%BS) Zygostates alleniana + Dipteranthus grandiflorus sister to a moderately supported (75\%BS) clade of Hintonella sister to a moderately supported $(85 \% \mathrm{BS})$ clade of a polytomy of Eloyella + Sphyrastylis dalstromii and a weakly supported (76\%BS) Ornithocephalus inflexus + Phymatidium falcifolium.

Analysis of the combined plastid matrix of matK/ trnL-F/atpB-rbcL intergenic spacer - The combined matrix consisted of 4082 characters, of which 1112 were variable and $520(13 \%)$ were potentially parsimony informative. The analysis yielded four trees of 1634 steps $[\mathrm{CI}=0.79$ ( 0.65 with uninformative characters excluded), $\mathrm{RI}=0.80]$. The combined matrix yielded a tree which most resembles the matK only results, but with better resolution and stronger support for several clades. Figure 5 shows one tree with branch lengths above the lines and bootstrap values below the lines.

Telipogon alliance: The Telipogon alliance is strongly supported (94\%BS) with Hofmeisterella + the Trichoceros clade (100\%BS) sister to the strongly supported $(100 \% \mathrm{BS})$ remainder of the alliance, which forms two strongly supported clades: a strongly supported (100\%BS) Telipogon ariasii-pulcherdalstromii clade, and the strongly supported (100\%BS) remainder. The latter clade has two supported clades: a weakly supported clade $(59 \% \mathrm{BS})$ consisting of the strongly supported $(100 \% \mathrm{BS})$ South America clade of three species of Stellilabium + the strongly supported (100\%BS) Telipogon nervosus-vargasii clade; and the moderately supported $(86 \% \mathrm{BS})$ Central American two groups of Telipogon (100\%BS) and Stellilabium (100\%BS). Within the Central American Telipogon clade, T. parvulus is sister to the moderately supported (79\%BS) other five species, and within that five species group only $T$. panamensis is resolved. Within the Central American Stellilabium clade, S. bullpenense is sister to the strongly supported $(96 \% \mathrm{BS})$ clade of $S$. aciculare $+(S$. barbozae $+S$. monteverdense $96 \% \mathrm{BS})$.

Ornithocephalus alliance: This strongly supported alliance $(100 \% \mathrm{BS})$ has two major clades: Zygostates alleniana + Dipteranthus grandiflorus with $100 \% \mathrm{BS}$ support is sister to a strongly supported $(96 \% \mathrm{BS})$ clade within which Phymatidium is sister to a moderately supported $(83 \% \mathrm{BS})$ trichotomous clade of Eloyella + Hintonella + a moderately supported $(71 \% \mathrm{BS})$ clade of Ornithocephalus inflexus + Sphyrastylis dalstromii.

Analysis of the combined ITS/plastid data set - The combined nuclear and plastid matrix had 4859 characters, of which 1487 were variable and $821(17 \%)$ were potentially parsimony informative. The analysis yielded 30 trees of 2568 steps [CI $=0.71$ ( 0.59 with uninformative characters excluded), $\mathrm{RI}=0.79]$. Figure 6 shows one of the trees obtained.

Telipogon alliance: The strongly supported (98\%BS) Telipogon alliance consists of Hofmeisterella and the Trichoceros clade (100\%BS) forming a polytomy with the strongly supported $(97 \% \mathrm{BS})$ remainder of the alliance, which has two major clades: the Telipogon ariasii-pulcher-dalstromii clade with $100 \% \mathrm{BS}$ and the remainder of the alliance with $100 \%$ BS. The Telipogon nervosus-vargasii clade (100\%BS), the clade of three South American species of Stellilabium (100\%BS) and the strongly supported (94\%BS) Central American Stellilabium clade $(100 \% \mathrm{BS})+$ Central American Telipogon clade $(100 \% \mathrm{BS})$ form a trichotomy. The Central American Stellilabium clade has S. bullpenense sister to a weakly supported $(67 \% \mathrm{BS})$ three species clade, within which is the strongly supported (100\%BS) S. barbozae-monteverdense clade. The Central American Telipogon clade has T. butcheri sister to the strongly supported $(96 \% \mathrm{BS})$ remaining five unresolved species.

Ornithocephalus alliance: This strongly supported (100\%BS) alliance consists of Phymatidium sister to a weakly supported $(57 \% \mathrm{BS})$ clade of the remainder which consists of a strongly supported (100\%BS) Zygostates alleniana + Dipteranthus grandiflorus sister to a strongly supported $(100 \% \mathrm{BS})$ trichotomy of Eloyella + Hintonella + a strongly supported $(100 \% \mathrm{BS})$ clade of Ornithocephalus inflexus + Sphyrastylis dalstromii.

Bayesian analysis of the combined ITS/plastid data set - Figure 7 is the tree obtained by Bayesian analysis of the combined plastid and ITS data sets. The monophyly of the Telipogon and Ornithocephalus alliances is supported by $100 \%$ posterior probability 
of each alliance. Strongly supported clades within the Telipogon alliance, as indicated by $100 \%$ posterior probability, are: Trichoceros; Telipogon + Stellilabium; the Telipogon ariasii-pulcher-dalstromii clade; the Telipogon nervosus-vargasii clade; the South American Stellilabium clade; the Central American Stellilabium clade; and the Central American Telipogon clade. The Ornithocephalus alliance shows $100 \%$ posterior probability support for Ornithocephalus inflexus + Sphyrastylis dalstromii as well as for Eloyella + Hintonella + Ornithocephalus + Sphyrastylis and for Zygostates alleniana + Dipteranthus grandiflorus.

Expanded ITS analysis of 81 taxa in Telipogon, Ornithocephalus, Pachyphyllum alliances - The ITS only matrix had 682 characters, of which 414 were variable and $352(52 \%)$ were potentially parsimony informative. The analysis yielded 251 trees of 1333 steps $[\mathrm{CI}=0.49$ (0.46 with uninformative characters excluded), RI $=0.89]$. Figure 8 shows one tree with bootstrap values and branch lengths. This expanded ITS analysis includes an additional eleven species of the Ornithocephalus alliance and allows us to place Hofmeisterella with the Telipogon alliance and not with the Ornithocephalus alliance with more confidence. The bootstrap analysis, with Lockhartia as the outgroup, shows a strongly supported $(100 \% \mathrm{BS})$ group of three clades: the strongly supported (96\%BS) Ornithocephalus alliance; the strongly supported (100\%BS) Pachyphyllum alliance; and the moderately supported (78\%BS) Telipogon alliance. The Telipogon alliance has three parts: 1) a strongly supported (100\%BS) Trichoceros clade; 2) a moderately supported (90\%BS) Telipogon clade of South American species; and 3) a moderately supported (78\%BS) clade of Hofmeisterella sister to a strongly supported $(100 \% \mathrm{BS})$ clade comprised of Stellilabium and the remaining species of Telipogon.

The first clade, Trichoceros, is still under study and will not be discussed further at this time. The second clade, the Telipogon venustus-T. ariasii group, is strictly South American. Two accessions of T. venustus are sister to polytomy of $T$. valenciae and the $T$. ariasii-T. falcatus clade. Within this latter clade (with $86 \% \mathrm{BS})$, T. falcatus is sister to a strongly supported clade $(100 \% \mathrm{BS})$ of eight species. Telipogon ariasii-T. frymirei have $91 \% \mathrm{BS}$ and $T$. chrysocrates-T. andicola have $87 \% \mathrm{BS}$.

This third clade consists of a strongly supported (100\%BS) South American clade of Telipogon klotzscheanus-nervosus-vargasii sister to a clade with moderate support $(74 \% \mathrm{BS})$ consisting of a strongly supported (100\%BS) South American Stellilabium clade and a moderately supported (84\%BS) clade of two Central American groups: a strongly supported (100\%BS) clade of Stellilabium species and a strongly supported $(98 \% \mathrm{BS})$ clade of Telipogon species. The Central American Stellilabium clade of six species consists of a strongly supported clade (100)\%BS) of S. aciculare, S. smaragdinum, and a species from the Dominican Republic (Stellilabium sp. n660, recently described by Ackerman, 2004, as a new species of Telipogon) sister to a weakly supported $(63 \% \mathrm{BS})$ clade of (S. barbozae + monteverdense $100 \% \mathrm{BS})+S$. bullpenense. The Central American Telipogon clade consists of $T$. butcheri sister to a strongly supported (100\%BS) clade of the remaining 18 species of Telipogon. Within the large clade of 18 species, the only groups resolved are the following: two accessions of $T$. parvulus with $99 \% \mathrm{BS}$; T. griesbeckii (two accessions) + T. olmosii with $58 \% \mathrm{BS}$; and a six species group with $64 \% \mathrm{BS}$ which includes a weakly supported (63\%BS) two species clade of $T$. panamensis and T. personatus.

Ornithocephalus alliance: This expanded ITS analysis of the Ornithocephalus alliance with 96\%BS support has two accessions of Phymatidium falcifolium sister to a moderately supported $(90 \% \mathrm{BS})$ remainder of the alliance. This group includes a strongly supported (100\%BS) clade of Eloyella, Hintonella, and Chytroglossa sister to a strongly supported (100\%BS) clade of Ornithocephalus and Sphyrastylis species. This latter clade has Sphyrastylis embedded within Ornithocephalus. The second major clade in this alliance is the strongly supported (99\%BS) Zygostates + Dipteranthus clade. Within this clade, D. pellucidus is sister to a clade with $70 \% \mathrm{BS}$ of $D$. grandiflorus sister to a strongly supported (100\%BS) D. obliquus $+Z$. lunata $+Z$. alleniana clade.

\section{DISCUSSION}

Molecular analyses - An analysis of 634 species in the Oncidiinae for ITS and 252 species for ITS/matK/ trnL-F (Williams et al. 2001a,b, Williams \& Whitten 2003, and unpublished) established that the TelipogonPachyphyllum - Ornithocephalus - Lockhartia alliances are sister groups embedded within the Oncidiinae. These earlier works and data reported here establish that Hofmeisterella is a part of the Telipogon alliance.

Taxonomic implications in the Telipogon alliance - Garay and Romero (1998) reinstated the genus Dipterostele Schltr. for a number of species of Stellilabium. We sampled one of those species, $S$. 
hystrix, which Dressler (1999) places in Stellilabium sect. Dipterostele. The molecular data $(100 \%$ bootstrap support for four genes, $100 \%$ posterior probability from Bayesian analysis) place $S$. hystrix as sister to a clade with Stellilabium pogonostalix, a species Dressler places in Stellilabium sect. Stellilabium and which Garay and Romero do not place in Dipterostele. Furthermore, the large analysis of ITS places $S$. hystrix within a clade containing $S$. boliviense and S. pogonostalix (Fig. 8) and five Ecuadorian species, which shows that Stellilabium section Dipterostele is not monophyletic. Dressler (1999) discusses a number of characters that distinguish these two sections of Stellilabium, and if Dipterostele were recognized, then the South American species of Stellilabium would have to be placed in at least three distinct genera. Stellilabium is not monophyletic (Figs. 1-8) and is embedded within Telipogon. Unless Telipogon is broken into three genera and Stellilabium into at least two genera representing the Central American clade and the South American clade (many more if Dipterostele is recognized), there is no way to have a monophyletic group without merging all of these groups into Telipogon. Dressler's Stellilabium sect. Taeniorhachis is not monophyletic and has Stellilabium sect. Rhamphostele embedded within it. At this time, more taxa are needed to resolve relationships of species usually placed in Stellilabium, but the "Stellilabium habit," which is essentially small flowers and a tendency to leaflessness at maturity, has arisen at least twice, once in South America and once in Central America, possibly from two different groups of Telipogon.

Braas and Lückel (1982) based their genus Darwiniella on Trichoceros bergoldii Garay \& Dunst. (Dunsterville \& Garay 1972), and Dressler (1999) states that it "is surely a robust member of this group", referring to Stellilabium sect. Stellilabium. Material of this species has not been available, but Dodson (2004) considers Darwiniella a synonym of Stellilabium.

The species listed as Stellilabium sp. D. Dod 168 from the Dominican Republic in the 81 OTU ITS analysis was initially identified as $S$. minutiflorum (Kraenzl.) Garay, but Ackerman has concluded that it is a new species and has named it Telipogon niri Ackerman in a separate publication (Ackerman 2004). This is the only species of the Telipogon alliance known from the Caribbean area.

Telipogon consists of three groups: 1) a Central American clade from Panama and Costa Rica; 2) one South American clade of Telipogon klotzscheanus-nervosus-vargasii; and 3) a second South American clade of T. venustus and the T. ariasii-va- lenciae complex. The combined plastid/ITS analysis places Hofmeisterella sister to all of the combined Telipogon + Stellilabium clades, with Trichoceros sister to this group (Fig. 6). If Stellilabium is combined with Telipogon, Hofmeisterella must also be placed in Telipogon. Although Trichoceros is vegetatively distinct from the other members of the Telipogon alliance, the flowers are an extreme manifestation of the pseudocopulation / mimicry pollination complex of characters. We prefer to maintain it as a separate genus because of the distinctive vegetative morphology and easily recognized field characters, such as the distinctive gray-green sheen of the succulent leaves, the distinct pseudobulbs, and the rambling, vine-like habit.

At this time we make formal transfers below of species of Stellilabium to Telipogon. Ackerman has already made one such combination in naming Telipogon niri Ackerman in a separate publication (Ackerman 2004) for a species from the Dominican Republic shown in Fig. 8 as Stellilabium sp. D. Dod 168. In essence, most of the species of Stellilabium are just small versions of Telipogon that often become leafless at maturity.

\section{Nomenclatural Changes}

\section{Telipogon acicularis (Dressler) N.H. Williams \& Dressler, comb. nov. \\ Basionym: Stellilabium aciculare Dressler, Harvard Pap. Bot. 4(2): 471-472, f. 1E-F. 1999.}

Telipogon alticola (Dodson \& R. Escobar) N.H. Williams \& Dressler, comb. nov.

Basionym: Stellilabium alticolum Dodson \& R. Escobar, Orquideología 20(1): 48. 1998.

\section{Telipogon anacristinae (Pupulin) N.H. Williams \& Dressler, comb. nov. \\ Basionym: Stellilabium anacristinae Pupulin, Harvard Pap. Bot. 8(1): 30, f. 1A-G. 2003.}

\section{Telipogon andinus (L.O. Williams) N.H. Williams \& Dressler, comb. nov.}

Stellilabium andinum (L.O. Williams) Garay \& Dunst., Orchids Venezuela: 1004. 1979.

Basionym: Cordanthera andina L.O. Williams, Lilloa 6: 244. 1941.

Telipogon astroglossus Rchb. f., Xenia Orchid. 1: 16, t. 7, f. II, 12-19. 1854.

= Stellilabium astroglossum (Rchb. f.) Schltr., Die Orchideen 530. 1914. 
The epithet atropurpurea is occupied in Telipogon by Telipogon atropurpurea D.E. Benn. \& Ric. Fernández, Publ. Mus. Hist. Nat. Univ. Nacion. Mayor San Marcos, Bot. 36: 9 (1992), and/or by Telipogon atropurpurea D.E. Benn. \& Ric. Fernández, Orquideophilo 5: 27 (1997). Either way, a new name is needed for the species known as Stellilabium atropurpureum P. Ortiz, Orquideologia 23(1): 24 (31), (2004), and we publish here the following name for this species:

\section{Telipogon ortizii N.H. Williams \& Dressler, nom. nov.}

The epithet honors Pedro Ortiz, who named the species originally.

Telipogon barbozae (J.T. Atwood \& Dressler) N.H. Williams \& Dressler, comb. nov.

Basionym: Stellilabium barbozae J.T. Atwood \& Dressler, Selbyana 16(2): 239, f. 1. 1995.

\section{Telipogon bennettii (Dodson \& R. Escobar) N.H. Williams \& Dressler, comb. nov.}

Stellilabium bennettii (Dodson \& R. Escobar) Christenson, Icon. Orchid. Peruviarum pl. 773. 2001.

Basionym: Trichoceros bennettii Dodson \& R. Escobar, Icon. Pl. Trop. II (2): t. 195. 1989.

\section{Telipogon bergoldii (Garay \& Dunst.) N.H.Williams \& Dressler, comb. nov. \\ Stellilabium bergoldii (Garay \& Dunst.) Carnevali \& G.A. Romero, in G.A. Romero \& G. Carnevali, Orchids Venezuela, ed. 2: 1147. 2000. \\ Darwiniella bergoldii (Garay \& Dunst.) Braas \& Lückel, Die Orchidee 33(5): 169. 1982, nom. illeg. \\ Darwiniera bergoldii (Garay \& Dunst.) Braas \& Lückel, Die Orchidee 33 (6): 212. 1982. \\ Basionym: Trichoceros bergoldii Garay \& Dunst., Venez. Orchids Ill. 5: 310. 1972.}

\section{Telipogon boliviensis (R. Vásquez \& Dodson) N.H.} Williams \& Dressler, comb. nov.

Basionym: Stellilabium boliviense R. Vásquez \& Dodson, Icon. P1. Trop. 6: t. 592. 1982.

\section{Telipogon boylei (J.T. Atwood) N.H. Williams \&} Dressler, comb. nov.

Basionym: Stellilabium boylei J.T. Atwood, Icon. Pl. Trop. 14: t. 1392. 1989.

Dipterostele boylei (J.T. Atwood) Garay \& G.A.
Romero, Harvard Pap. Bot. 3: 57. 1998.

\section{Telipogon bullpenensis (J.T. Atwood) N.H. Williams} \& Dressler, comb. nov.

Basionym: Stellilabium bullpenense J.T. Atwood, Icon. Pl. Trop. 14: t. 1393. 1989.

The epithet butcheri is occupied in Telipogon by Telipogon butcheri Dodson \& R. Escobar, Orquideologia 18: 278 (1993) and the species known as Stellilabium butcheri Dressler, Harvard Pap. Bot. 4(2): 472-473, f. $1 \mathrm{G}$ (1999) needs a new name. Telipogon chiriquensis is already taken and T. panamensis is taken. We publish here the following name for the species known as Stellilabium butcheri Dressler:

\section{Telipogon butchii N.H. Williams \& Dressler, nom. nov.}

The specific epithet refers to the affectionate nickname used by everyone who knew Henry Butcher.

Telipogon campbelliorum (J.T. Atwood) N.H. Williams \& Dressler, comb. nov.

Basionym: Stellilabium campbelliorum J.T. Atwood, Icon. Pl. Trop. 14: t. 1394. 1989.

Telipogon distantiflorus (Ames \& C. Schweinf.) N.H. Williams \& Dressler, comb. nov.

Basionym: Stellilabium distantiflorum Ames \& C. Schweinf., Sched. Orchid. 8: 70. 1925.

Dipterostele distantiflorum (Ames \& C. Schweinf.) Garay \& G.A.Romero, Harvard Pap. Bot. 3: 57. 1998.

Telipogon erratus (Dressler) N.H. Williams \& Dressler, comb. nov.

Basionym: Stellilabium erratum Dressler, Lankesteriana: 2: 11-13, f. 1. 2001.

Telipogon fortunae (Dressler) N.H. Williams \& Dressler, comb. nov.

Basionym: Stellilabium fortunae Dressler, Harvard Pap. Bot. 4(2): 473, f. 1B-D. 1999.

The epithet frymirei is occupied in Telipogon by Telipogon frymirei Dodson, Icon. Pl. Trop. 10: t. 991 (1984), and the species known as Stellilabium frymirei Dodson, Icon. Pl. Trop. 5: t. 495 (1982) needs a new name. We publish here the following name for this species: 
Telipogon embreei N.H. Williams \& Dressler, nom. nov.

The epithet honors the late Alvin Embree, who accompanied us on many field trips, found numerous new species of orchids, and was present at the collection of the type specimen of this species.

Dipterostele frymirei (Dodson) Garay \& G.A. Romero, Harvard Pap. Bot. 3: 57. 1998.

\section{Telipogon helleri (L.O. Williams) N.H. Williams \& Dressler, comb. nov. \\ Basionym: Stellilabium helleri L.O. Williams, Brittonia 14: 443. 1962. \\ Dipterostele helleri (L.O. Williams) Garay \& G.A. Romero, Harvard Pap. Bot. 3: 57. 1998.}

The epithet hirtzii is occupied in Telipogon by Telipogon hirtzii Dodson \& R. Escobar, Icon. P1. Trop. II (6): t. 590 (1989) and the species known as Stellilabium hirtzii Dodson, Icon. P1. Trop. 10: pl. 982 (1984) needs a new name. We publish here the following name for this species:

Telipogon alexii N.H. Williams \& Dressler, nom. nov.

The epithet honors the same person.

Telipogon hystrix (Dodson) N.H. Williams \& Dressler, comb. nov.

Basionym: Stellilabium hystrix Dodson, Icon. P1. Trop. 5: t. 496. 1982.

Dipterostele hystrix (Dodson) Garay \& G.A. Romero, Harvard Pap. Bot. 3: 57. 1998.

\section{Telipogon ibischii (R. Vásquez) N.H. Williams \&} Dressler, comb. nov.

Basionym: Stellilabium ibischii R. Vásquez, Lindleyana 13(2): 61. 1998.

\section{Telipogon jostii (Dodson) N.H.Williams \& Dressler,} comb. nov.

Basionym: Stellilabium jostii Dodson, Nat. Ecuad. Orch. 5: 1180. 2004.

Telipogon lankesteri Ames, Sched. Orchid. 3: 23. 1923.

Stellilabium lankesteri (Ames) Dressler, Novon 7(2): 124. 1997.

Dipterostele lankesteri (Ames) Garay \& G.A. Romero, Harvard Pap. Bot. 3: 57. 1998.

The epithet lueri is occupied in Telipogon by
Telipogon lueri Dodson \& D.E. Benn., Icon. Pl. Trop. II(2): t. 190 (1989), and the species known as Stellilabium lueri Dodson \& R. Vásquez, Icon. Pl. Trop. II(4): t. 381 (1989) needs a new name. We publish here the following name for this species:

\section{Telipogon calueri N.H. Williams \& Dressler, nom. nov.}

The epithet refers to the first two initials of the name of the same person, Carl A. Luer.

Dipterostele lueri (Dodson \& R. Vásquez) Garay \& G.A. Romero, Harvard Pap. Bot. 3: 57. 1998.

Telipogon microglossus (Schltr.) N.H. Williams \& Dressler, comb. nov.

Stellilabium microglossum (Schltr.) Dodson, Icon. Pl. Trop. 4: pl. 334. 1980.

Basionym: Dipterostele microglossa Schltr., Repert. Spec. Nov. Regni Veg. 8: 106. 1921.

Telipogon minutiflorus Kraenzl, Ann. Naturhist. Hofmus. 33: 14. 1920.

Stellilabium minutiflorum (Kraenzl.) Garay, J. Arnold Arbor. 50: 446. 1969.

Dipterostele minutiflora (Kraenzl.) Schltr., Repert. Spec. Nov. Regni Veg. Beih. 19: 70. 1923.

Telipogon monteverdensis (J.T. Atwood) N.H. Williams \& Dressler, comb. nov.

Basionym: Stellilabium monteverdense J.T. Atwood, Icon. Pl. Trop. 14: t. 1395. 1989.

Telipogon morganiae (Dodson) N.H. Williams \& Dressler, comb. nov.

Basionym: Stellilabium morganiae Dodson, Icon. P1. Trop. 1: t. 335. 1980.

Dipterostele morganiae (Dodson) Braas \& Lückel, Die Orchidee 33: 175. 1982.

Telipogon morii (Dressler) N.H. Williams \& Dressler, comb. nov.

Basionym: Stellilabium morii Dressler, Harvard Pap. Bot. 4(2): 473, fig. 1H. 1999.

Telipogon pampatamboensis (Dodson \& R. Vásquez) N.H. Williams \& Dressler, comb. nov.

Basionym: Stellilabium pampatamboense Dodson \& R. Vásquez, Icon. Pl. Trop. II(4): t. 382. 1989.

Telipogon perlobatus (Senghas) N.H. Williams \& Dressler, comb. nov.

Basionym: Stellilabium perlobatum Senghas, J. 
Orchideenfreund 1: 172. 1994

The species known as Stellilabium peruvianum D.E. Benn. \& Christenson, Lindleyana 13(2): 8688 , f. 30 (1998) needs a new name, as the epithet is used in Telipogon already by Telipogon peruvianus T. Hashim., Bull. Natl. Sci. Mus., Tokyo, B 16: 21 (1990). We publish here the following name for the species known as Stellilabium peruvianum D.E. Benn. \& Christenson:

\section{Telipogon selbyanus N.H.Williams \& Dressler, nom. nov.}

The epithet honors the Marie Selby Botanical Gardens, an organization which has promoted the scientific study of orchids for three decades.

Telipogon pogonostalix Rchb.f., Linnaea 41: 72. 1876. Stellilabium pogonostalix (Rchb. f.) Garay \& Dunst., Venez. Orchids Ill. 2: 336. 1961.

Sodiroella ecuadorensis Schltr., Repert. Spec. Nov. Regni Veg. Beih. 8: 108. 1921, is a synonym according to Dodson (1998: 50-51).

\section{Telipogon pseudobulbosus (D.E. Benn. \& Christ-} enson) N.H. Williams \& Dressler, comb. nov.

Basionym: Stellilabium pseudobulbosum D.E. Benn. \& Christenson, Lindleyana 13(2): 88, f. 31. 1998.

\section{Telipogon smaragdinus (Pupulin \& M.A. Blanco)} N.H. Williams \& Dressler, comb. nov.

Basionym: Stellilabium smaragdinum Pupulin \& M.A. Blanco, Lankesteriana 5: 28-30. 2002.

Telipogon standleyi Ames, Sched. Orch. 9: 53, f. 9. 1925.

Stellilabium standleyi (Ames) L.O. Williams, Brittonia 14: 46. 1962.

Dipterostele standleyi (Ames) Garay \& G.A. Romero, Harvard Pap. Bot. 3: 58. 1998.

\section{Telipogon tanii (Dodson) N.H. Williams \& Dressler, comb. nov.}

Basionym: Stellilabium tanii Dodson, Icon. Pl. Trop. 1: t. 337. 1980.

Possibly = Stellilabium astroglossum (Rchb.f.) Schltr., Orchideen: 530. 1914, fide Kew Monocot List

Dipterostele tanii (Dodson) Garay \& G.A. Romero, Harvard Pap. Bot. 3: 58. 1998.

\section{Telipogon tsipiriensis (Pupulin) N.H. Williams \& Dressler, comb. nov. \\ Basionym: Stellilabium tsipiriense Pupulin, Harvard}

Pap. Bot. 8(1): 30, f. 2A-H, L. 2003.

The epithet vasquezii is occupied in Telipogon by Telipogon vasquezii Dodson, Selbyana 7: 358 (1984), and the species known as Stellilabium vasquezii Dodson, Icon. Pl. Trop. 6: t. 593 (1982) needs a new name. There is already (or will be, see above) a Telipogon boliviensis, so we publish here the following name for the species known as Stellilabium vasquezii Dodson:

\section{Telipogon roberti N.H. Williams \& Dressler, nom. nov.}

The epithet honors the same person, but refers to his first name, Roberto, latinized as Robertus (Genitive Roberti).

Dipterostele vasquezii (Dodson) Garay \& G.A. Romero, Harvard Pap. Bot. 3: 58. 1998.

Non Telipogon vasquezii Christenson, Icon. Orchid. Peruv.: t. 784. 2001, nom. illeg.

The epithet vulcanicum is occupied in Telipogon by Telipogon vulcanicum Dodson \& Hirtz, Nat. Ecuad. Orch. 5: 1186 (2004), thus the species known as Stellilabium vulcanicum Dodson \& Hirtz, Nat. Ecuad. Orch. 5: 1181 (2004) needs a new name. We publish here the following name for this species:

\section{Telipogon reventadorensis N.H. Williams \& Dressler, nom. nov.}

The epithet refers to the location (Volcán Reventador, Ecuador) where the type was collected.

The work reported here definitely establishes that Hofmeisterella is not associated with members of the Ornithocephalus alliance as Szlachetko (1995) suggested, but rather is firmly associated with the Telipogon alliance in the Oncidiinae. Reichenbach originally placed this species in his genus Hofmeistera (De Pollinis Orchidearum 30. 1852), but later in the same year apparently decided that this name was too close to Hofmeisteria Walp. [published in: Repertorium Botanices Systematicae 6: 106. 1846 ("1847") as a member of the Asteraceae], and renamed it Hofmeisterella.

The current work (as well as previous work, Whitten et al. 2000, Williams et al. 2001 a, b, Whitten et al. 2005) shows that the Fernandezia / Pachyphyllum group is associated with these alliances, rather than with Dichaea as Szlachetko (1995) suggested. Fernandezia and Pachyphyllum form a clade with $100 \% \mathrm{BS}$ in the 81 
taxon ITS analysis. A more comprehensive study of the Fernandezia / Pachyphyllum group is underway.

Taxonomic implications in the Ornithocephalus alliance - Toscano de Brito and Dressler (2000) transferred all species of Sphyrastylis to Ornithocephalus based on morphological studies, and studies of pollinarium morphology and leaf anatomy also supported this transfer (Toscano de Brito 1994, 1998). The molecular data presented here (Fig. 8) confirm this decision. In the ITS trees Zygostates is nested within Dipteranthus, but until we have a more comprehensive study of the Ornithocephalus alliance we refrain from making these nomenclatural changes.

Biogeographic implications - The Central American Telipogon clade (Fig. 8) has very little sequence divergence for ITS, and only moderate sequence divergence for the combined plastid regions. The Stellilabium component of this clade has more ITS divergence among species than the Telipogon component. The lack of sequence divergence in the Telipogon component suggests rapid evolution of this group from a South American introduction.

Acknowledgments. We thank Mario Blanco, Stig Dalström, Ron Determann, Calaway H. Dodson, Lorena Endara, Günter Gerlach, Cordelia Head, Andres Maduro, Erich Michel, José Portilla, Franco Pupulin, Gustavo Romero, and Jorge Warner for plant specimens and access to collections. We thank Wendy Zomlefer for many constructive comments on the manuscript. This work was supported by NSF grants DEB 9815821 to NHW and DEB 9509071 to WMW, by grants from the American Orchid Society Fund for Education and Research, and the Florida Museum of Natural History.

\section{LiTERATURE CITED}

Ackerman, J.D. 2004. Notes on the Caribbean orchid flora. V. New species, combinations and records. Lankesteriana 4: 47-56.

Braas, L.A. \& E. Lückel. 1982. Darwiniella, eine neue Gattung der Subtribus Telipogoninae Schltr. Die Orchidee 33: 167-176.

Chiang, T.Y., B.A. Schaal \& C.I. Peng. 1998. Universal primers for amplification and sequencing a noncoding spacer between the atpB and $r b c L$ genes of chloroplast DNA. Bot. Bull. Acad. Sin. 39: 245-250.

Dodson, C.H. 1998. New orchid species and combinations from Ecuador-Fascicle 6. Orquideología
21: 3-60.

Dodson, C.H. 2004. Native Ecuadorian Orchids 5: 1014.

Dressler, R.L. 1993. Phylogeny and Classification of the Orchid Family. Dioscorides Press. Portland, OR. 314 p.

Dressler, R.L. 1999. A reconsideration of Stellilabium and Dipterostele. Harvard Pap. Bot. 4: 469-473.

Dunsterville, G.C.K. \& L.A. Garay. 1972. Venezuelan Orchids Illustrated 5: 310.

Fitch, W.M. 1971. Toward defining the course of evolution: minimal change for a specific tree topology. Syst. Zool. 20: 406-416.

Garay, L.A. \& G.A. Romero-González. 1998. Schedulae Orchidum. Harvard Pap. Bot. 3: 53-62.

Huelsenbeck, J.P. \& F. Ronquist. 2001. MrBayes: Bayesian inference of phylogenetic trees. Bioinformatics 17: 754-755.

Sun, Y., D.Z. Skinner, G.H. Liang \& S.H. Hulbert. 1994. Phylogenetic analysis of Sorghum and related taxa using internal transcribed spacers of nuclear ribosomal DNA. Theor. Appl. Genet. 89: 26-32.

Swofford, D.L. 2000. PAUP*: Phylogenetic Analysis Using Parsimony (*and Other Methods). Version 4.0b2. Sinauer Assoc., Sunderland, Mass.

Szlachetko, D.L. 1995. Systema Orchidalium. Fragm. Flor. Geobot. Suppl. 3: 1-152.

Taberlet, P., L. Gielly, G. Pautou \& J. Bouvet. 1991. Universal primers of amplification of three noncoding regions of chloroplast DNA. Pl. Mol. Biol. 17: 1105-1109.

Toscano de Brito, A.L.V. 1994. Systematic studies in the subtribe Ornithocephalinae (Orchidaceae). $\mathrm{Ph}$. D. thesis, University of Reading, Reading, England.

Toscano de Brito, A.L.V. 1998. Leaf anatomy of Ornithocephalinae (Orchidaceae) and related subtribes. Lindleyana 13: 234-258.

Toscano de Brito, A.L.V. \& R.L. Dressler. 2000. New combinations in Ornithocephalus (Ornithocephalinae: Orchidaceae) and description of a new species from Mesoamerica. Lindleyana 15: 252-256.

Whitten, W.M., N.H. Williams \& M.W. Chase. 2000. Subtribal and generic relationships of Maxillarieae (Orchidaceae) with emphasis on Stanhopeinae: combined molecular evidence. Amer. J. Bot. 87: 1842-1856.

Whitten, W.M., N.H. Williams, R.L. Dressler, G. Gerlach \& F. Pupulin. 2005. Generic relationships of Zygopetalinae(Orchidaceae: Cymbidieae): combined molecular evidence. Lankesteriana 5: 87-108. 
Williams, N.H., M.W. Chase, T. Fulcher \& W.M. Whitten. 2001a. Molecular systematics of the Oncidiinae based on evidence from four DNA sequence regions: expanded circumscriptions of Cyrtochilum, Erycina, Otoglossum, and Trichocentrum and a new genus (Orchidaceae). Lindleyana 16: 113-139.

Williams, N.H., M.W. Chase \& W.M. Whitten. 2001 b.
Phylogenetic position of Miltoniopsis, Caucaea, a new genus, Cyrtochiloides, and relationship of Oncidium phymatochilum based on nuclear and chloroplast DNA sequence data (Orchidaceae: Oncidiinae). Lindleyana 16: 272-285.

Williams, N.H. \& W.M. Whitten. 2003. Molecular phylogenetics and generic concepts in the Maxillarieae (Orchidaceae). Lankesteriana 7: 61-62.

Table 1. Vouchers and GenBank accessions.

\begin{tabular}{|c|c|c|c|c|c|c|}
\hline $\begin{array}{l}\text { Table } 1 . \text { Vouchers and GenBank } \\
\text { accessions. }\end{array}$ & & & & & & \\
\hline Taxon & Voucher & Herb. & ITS & $\operatorname{trn} L-F$ & matK & $\begin{array}{l}\text { atpB-rbcL } \\
\text { spacer }\end{array}$ \\
\hline Chytroglossa marileoniae Rchb.f. & Whitten 2949 & FLAS & DQ315817 & & & \\
\hline Dipteranthus grandiflorus (Lindl.) Pabst & Chase 103 & $\mathrm{~K}$ & AF350508 & AF350666 & AF350587 & \\
\hline $\begin{array}{l}\text { Dipteranthus obliquus (Schnee) Garay } \\
\text { \& Dunst. }\end{array}$ & $\begin{array}{l}\text { Gerlach } \\
93 / 3251\end{array}$ & FLAS & DQ315818 & & & \\
\hline Dipteranthus pellucidus (Rchb.f.) Cogn. & Whitten 2792 & FLAS & DQ315819 & & & \\
\hline Eloyella thienii Dodson & Whitten 1833 & FLAS & DQ315820 & DQ315916 & DQ315888 & DQ315792 \\
\hline $\begin{array}{l}\text { Fernandezia ionanthera (Rchb.f. \& } \\
\text { Warsz.) Schltr. }\end{array}$ & $\begin{array}{l}\text { Whitten } \\
97069\end{array}$ & FLAS & AF239390 & AF239582 & AF239486 & \\
\hline Fernandezia sp. & Chase 89096 & $\mathrm{~K}$ & AF350506 & AF350664 & AF350585 & \\
\hline $\begin{array}{l}\text { Fernandezia tica Mora-Ret. \& J.B. } \\
\text { García }\end{array}$ & Maduro 240 & MO & DQ315821 & DQ315917 & DQ315889 & DQ315793 \\
\hline Hintonella mexicana Ames & Williams s.n. & FLAS & DQ315822 & DQ315918 & DQ315890 & DQ315794 \\
\hline $\begin{array}{l}\text { Hofmeisterella eumicroscopica (Rchb. } \\
\text { f.) Rchb.f. \#1 }\end{array}$ & Chase 112 & $\mathrm{~K}$ & AF350510 & DQ315919 & AF350589 & \\
\hline $\begin{array}{l}\text { Hofmeisterella eumicroscopica (Rchb. } \\
\text { f.) Rchb.f. \#2 }\end{array}$ & Whitten 2690 & FLAS & DQ315823 & & & \\
\hline Lockhartia amoena Endres \& Rchb.f. & Chase 84101 & $\mathrm{~K}$ & AF350515 & AF350673 & AF350594 & \\
\hline Lockhartia oerstedii Rchb.f & Whitten s.n. & FLAS & AF350514 & AF350672 & AF350593 & \\
\hline $\begin{array}{l}\text { Ornithocephalus grexanserinus } \\
\text { Dressler \& Mora-Ret. }\end{array}$ & UF98009 & FLAS & DQ315824 & & & \\
\hline Ornithocephalus inflexus Lindl. & Blanco 2645 & USJ & AF350507 & AF350665 & DQ315891 & \\
\hline Ornithocephalus iridifolius Rchb.f. & $\begin{array}{l}\text { Gerlach } \\
93 / 904\end{array}$ & M & DQ315825 & & & \\
\hline Ornithocephalus kruegeri Rchb.f. & $\begin{array}{l}\text { Gerlach } \\
93 / 3569\end{array}$ & M & DQ315826 & & & \\
\hline Ornithocephalus myrticola Lindl. & $\begin{array}{l}\text { Gerlach } \\
92 / 3881\end{array}$ & M & DQ315827 & & & \\
\hline Pachyphyllum sp. & Chase 87105 & $\mathrm{~K}$ & DQ315828 & & & \\
\hline Pachyphyllum sp. & Whitten 2313 & FLAS & DQ315829 & & & \\
\hline
\end{tabular}




\begin{tabular}{|c|c|c|c|c|c|c|}
\hline Pachyphyllum sp. & Whitten 2453 & FLAS & DQ315830 & & & \\
\hline Pachyphyllum sp. & Whitten 1614 & FLAS & DQ315832 & DQ315920 & DQ315892 & DQ315795 \\
\hline Pachyphyllum sp. & Whitten 1703 & FLAS & DQ315833 & & & \\
\hline Pachyphyllum cuencae Rchb.f. & Whitten 2537 & FLAS & DQ315831 & & & \\
\hline Phymatidium falcifolium Lindl. & Whitten 1831 & FLAS & DQ315834 & & DQ315893 & DQ315796 \\
\hline Sphyrastylis dalstromii Dodson & Williams s.n. & FLAS & DQ315835 & DQ315921 & DQ315894 & DQ315797 \\
\hline Sphyrastylis escobariana Garay & Whitten 2693 & FLAS & AF350509 & AF350667 & AF350588 & DQ315 \\
\hline Sphyrastylis sp. & \begin{tabular}{|l|} 
Dalstrom \\
2355
\end{tabular} & SEL & DQ315836 & & & \\
\hline Stellilabium aciculare Dressler & Dressler 3617 & MO & DQ315837 & DQ315922 & DQ315896 & DQ315798 \\
\hline $\begin{array}{l}\text { Stellilabium barbozae Atwood \& } \\
\text { Dressler }\end{array}$ & Pupulin 4710 & USJ & DQ315838 & DQ315923 & DQ315897 & DQ315799 \\
\hline $\begin{array}{l}\text { Stellilabium boliviense R.Vásquez \& } \\
\text { Dodson }\end{array}$ & $\begin{array}{l}\text { Dalstrom } \\
2397\end{array}$ & SEL & DQ315839 & & & \\
\hline Stellilabium bullpenense Atwood & Pupulin 4729 & USJ & DQ315840 & DQ315924 & DQ315898 & DQ315800 \\
\hline Stellilabium hystrix Dodson & Whitten 1824 & FLAS & DQ315841 & DQ315925 & DQ315899 & DQ315801 \\
\hline Stellilabium monteverdense Atwood & Pupulin 4731 & USJ & DQ315842 & DQ315926 & DQ315900 & DQ315802 \\
\hline $\begin{array}{l}\text { Stellilabium pogonostalix (Rchb.f.) } \\
\text { Garay \& Dunst. }\end{array}$ & Chase 123 & $\mathrm{~K}$ & AF350511 & AF350669 & DQ315901 & \\
\hline $\begin{array}{l}\text { Stellilabium smaragdinum Pupulin \& } \\
\text { M.A. Blanco }\end{array}$ & Whitten 2155 & FLAS & DQ315844 & & & \\
\hline $\begin{array}{l}\text { Stellilabium sp. }=\text { Telipogon niri } \\
\text { Ackerman }\end{array}$ & D. Dod 168 & NY & DQ315843 & & & \\
\hline Stellilabium sp. & Whitten 2530 & FLAS & DQ315845 & & & \\
\hline Stellilabium sp. & Whitten 2531 & FLAS & DQ315846 & & & \\
\hline Stellilabium sp. & Whitten 2532 & FLAS & DQ315847 & & & \\
\hline Stellilabium sp. & Whitten 2533 & FLAS & DQ315848 & & & \\
\hline Stellilabium $\mathrm{sp}$. & Hirtz 7103 & QCNE & DQ315849 & DQ315927 & DQ315895 & DQ315803 \\
\hline Telipogon ampliflorus C. Schweinf. & Maduro 253 & FLAS & DQ315850 & & & \\
\hline Telipogon andicola Rchb.f. & Escobar 3603 & FLAS & DQ315851 & & & \\
\hline Telipogon ariasii Dodson \& D.E. Benn. & Maduro 235 & FLAS & DQ315852 & DQ315928 & DQ315902 & \\
\hline Telipogon biolleyi Schltr. & Maduro 242 & FLAS & DQ315853 & DQ315929 & DQ315903 & \\
\hline Telipogon bombiformis Dressler & Maduro 138 & FLAS & DQ315854 & & & \\
\hline $\begin{array}{l}\text { Telipogon butcheri Dodson \& R. } \\
\text { Escobar }\end{array}$ & Maduro 208 & FLAS & DQ315855 & DQ315930 & DQ315904 & DQ315805 \\
\hline Telipogon caulescens Dressler \#1 & Maduro 168 & MO & DQ315856 & DQ315931 & DQ315905 & DQ315806 \\
\hline
\end{tabular}




\begin{tabular}{|c|c|c|c|c|c|c|}
\hline Telipogon caulescens Dressler \#2 & $\begin{array}{l}\text { Gerlach } \\
02 / 3089 \\
\end{array}$ & M & DQ315857 & & & \\
\hline $\begin{array}{l}\text { Telipogon chiriquensis Dodson \& R. } \\
\text { Escobar }\end{array}$ & Maduro 192 & FLAS & DQ315858 & & & \\
\hline Telipogon chrysocrates Rchb.f. & Escobar 2673 & FLAS & DQ315859 & & & \\
\hline Telipogon costaricensis Schltr. & photo & FLAS & DQ315860 & & & \\
\hline Telipogon dalstromii Dodson & Maduro 233 & FLAS & DQ315861 & DQ315932 & DQ315906 & DQ315807 \\
\hline Telipogon falcatus Linden \& Rchb.f. & Escobar 3353 & FLAS & DQ315862 & & & \\
\hline Telipogon frymirei Dodson & $\begin{array}{l}\text { Dodson } \\
17390\end{array}$ & FLAS & DQ315863 & & & \\
\hline Telipogon griesbeckii Dressler \#1 & Maduro 169 & MO & DQ315864 & & & \\
\hline Telipogon griesbeckii Dressler \#2 & Maduro 169 & FLAS & DQ315865 & & & \\
\hline Telipogon klotzscheanus Rchb.f. & $\begin{array}{l}\text { Gerlach } \\
95 / 3136\end{array}$ & FLAS & DQ315866 & & & \\
\hline Telipogon maduroi Dressler & Maduro 190 & MO & DQ315867 & & & \\
\hline Telipogon medusae Dressler & Maduro 209 & MO & DQ315868 & & & \\
\hline Telipogon monticola L.O. Williams & Maduro 241 & MO & DQ315869 & & & \\
\hline Telipogon nervosus (L.) Druce & $\begin{array}{l}\text { Gerlach } \\
94 / 3958 \\
\end{array}$ & M & DQ315870 & DQ315933 & DQ315907 & DQ315808 \\
\hline Telipogon olmosii Dressler & Maduro 213 & MO & DQ315871 & & DQ315 & DQ315 \\
\hline $\begin{array}{l}\text { Telipogon panamensis Dodson \& R. } \\
\text { Escobar }\end{array}$ & Maduro 194 & MO & DQ315872 & DQ315934 & DQ315908 & DQ315809 \\
\hline Telipogon parvulus C. Schweinf. \#1 & Williams s.n. & FLAS & DQ315873 & DQ315935 & DQ315909 & DQ315810 \\
\hline Telipogon parvulus C. Schweinf. \#2 & Maduro 193 & PMA & AF350513 & AF350671 & AF350592 & \\
\hline Telipogon personatus Dressler & Maduro 214 & PMA & DQ315874 & & & \\
\hline Telipogon pulcher Rchb.f. & $\begin{array}{l}\text { Gerlach 97- } \\
3608\end{array}$ & M & DQ315875 & DQ315936 & DQ315910 & DQ315811 \\
\hline $\begin{array}{l}\text { Telipogon seibertii Dodson \& R. } \\
\text { Escobar }\end{array}$ & Maduro 191 & PMA & DQ315876 & DQ315937 & DQ315911 & DQ315812 \\
\hline Telipogon sp. & Whitten 2412 & FLAS & DQ315877 & & & \\
\hline Telipogon sp. & Whitten 2413 & FLAS & DQ315878 & & & \\
\hline $\begin{array}{l}\text { Telipogon valenciae Dodson \& R. } \\
\text { Escobar }\end{array}$ & Escobar 4015 & FLAS & DQ315879 & & & \\
\hline Telipogon vargasii C. Schweinf. & $\begin{array}{l}\text { Gerlach } \\
95 / 2450\end{array}$ & M & DQ315880 & DQ315938 & DQ315912 & DQ315813 \\
\hline Telipogon venustus Schltr. \#1 & $\begin{array}{l}\text { Hirtz et al. } \\
2302\end{array}$ & FLAS & DQ315881 & & & \\
\hline Telipogon venustus Schltr. \#2 & $\begin{array}{l}\text { Gerlach } \\
03 / 1489\end{array}$ & M & DQ315882 & & & \\
\hline $\begin{array}{l}\text { Trichoceros antennifer (Humb. \& } \\
\text { Bonpl.) Kunth }\end{array}$ & Whitten 1803 & FLAS & DQ315883 & & & \\
\hline Trichoceros muralis Lindl. & No voucher & & DQ315884 & DQ315940 & DQ315914 & DQ315814 \\
\hline
\end{tabular}




\begin{tabular}{|l|l|l|l|l|l|l|}
\hline Trichoceros parviflorus Kunth & Chase 138 & K & AF350512 & AF350670 & AF350591 & DQ315 \\
\hline Trichoceros sp. & Whitten 2353 & FLAS & DQ315885 & DQ315939 & DQ315913 & DQ315815 \\
\hline Zygostates alleniana Kraenzl. & $\begin{array}{l}\text { Gerlach } \\
95 / 2428\end{array}$ & M & DQ315886 & DQ315941 & DQ315915 & DQ315816 \\
\hline Zygostates lunata Lindl. & $\begin{array}{l}\text { Gerlach } \\
92 / 3883\end{array}$ & M & DQ315887 & & & \\
\hline
\end{tabular}

Table 2. Primers used in this study.

\begin{tabular}{|l|c|c|c|}
\hline Region & Primer name & Sequence & Reference \\
\hline ITS forward & $17 \mathrm{SE}$ & acgaattcatggtccggtgaagtgttcg & Sun et al. $(1994)$ \\
\hline ITS reverse & $26 \mathrm{SE}$ & tagaattccccggttcgctcgccgttac & Sun et al. $(1994)$ \\
\hline trnL-F forward & $\mathrm{C}$ & cgaaatcggtagacgctacg & Taberlet et al. $(1991)$ \\
\hline trnL-F reverse & $\mathrm{F}$ & atttgaactggtgacacgag & Taberlet et al. $(1991)$ \\
\hline$m a t K$ forward & $56 \mathrm{~F}$ & acttcctctatccgctactcctt & Williams et al. $(2001)$ \\
\hline$m a t K$ reverse & $1520 \mathrm{R}$ & cggataatgtccaaataccaaata & Williams et al. $(2001)$ \\
\hline $\begin{array}{l}a t p B-r b c L \text { intergenic spacer } \\
\text { forward }\end{array}$ & atpBmaxF & agaagtagtgggattgcttctc & \\
\hline $\begin{array}{l}a t p B-r b c L \text { intergenic spacer } \\
\text { reverse }\end{array}$ & atpBmaxR & tcacaacaacaaggtctactcg & \\
\hline
\end{tabular}

Table 3. Statistics from PAUP* analyses of separate and combined data matrices for the combined data set of 30 taxa in the Telipogon and Ornithocephalus alliances and 81 OTU's for the ITS only analysis.

\begin{tabular}{|c|c|c|c|c|c|c|c|}
\hline & ITS & $\operatorname{trn} L-F$ & matK & $\begin{array}{c}a t p B-r b c L \\
\text { spacer }\end{array}$ & $\begin{array}{c}\text { Combined } \\
\text { plastid }\end{array}$ & $\begin{array}{c}\text { ITS and } \\
\text { plastid } \\
30 \text { taxa }\end{array}$ & $\begin{array}{l}\text { ITS only } \\
81 \text { OTU's }\end{array}$ \\
\hline $\begin{array}{l}\text { \# included positions in } \\
\text { matrix }\end{array}$ & 795 & 1252 & 1331 & 1499 & 4082 & 4859 & 682 \\
\hline \# variable sites & 375 & 298 & 284 & 530 & 1112 & 1487 & 414 \\
\hline $\begin{array}{l}\text { \# phylogenetically } \\
\text { informative sites }\end{array}$ & 301 & 149 & 151 & 220 & 520 & 821 & 341 \\
\hline$\#$ of trees (Fitch) & 8 & 1458 & 4 & 3 & 4 & 30 & 252 \\
\hline \# of steps & 914 & 425 & 434 & 761 & 1634 & 2568 & 1311 \\
\hline $\mathrm{CI}$ & 0.58 & 0.80 & 0.76 & 0.81 & 0.79 & 0.71 & 0.49 \\
\hline $\begin{array}{l}\text { CI excluding non- } \\
\text { informative sites }\end{array}$ & 0.54 & 0.68 & 0.64 & 0.65 & 0.65 & 0.59 & 0.46 \\
\hline RI & 0.79 & 0.84 & 0.83 & 0.75 & 0.80 & 0.79 & 0.88 \\
\hline $\begin{array}{l}\text { Ave. \# of changes per } \\
\text { variable site (\# steps/\# } \\
\text { var. sites) }\end{array}$ & 2.44 & 1.43 & 1.53 & 1.44 & 1.47 & 1.73 & 3.17 \\
\hline
\end{tabular}




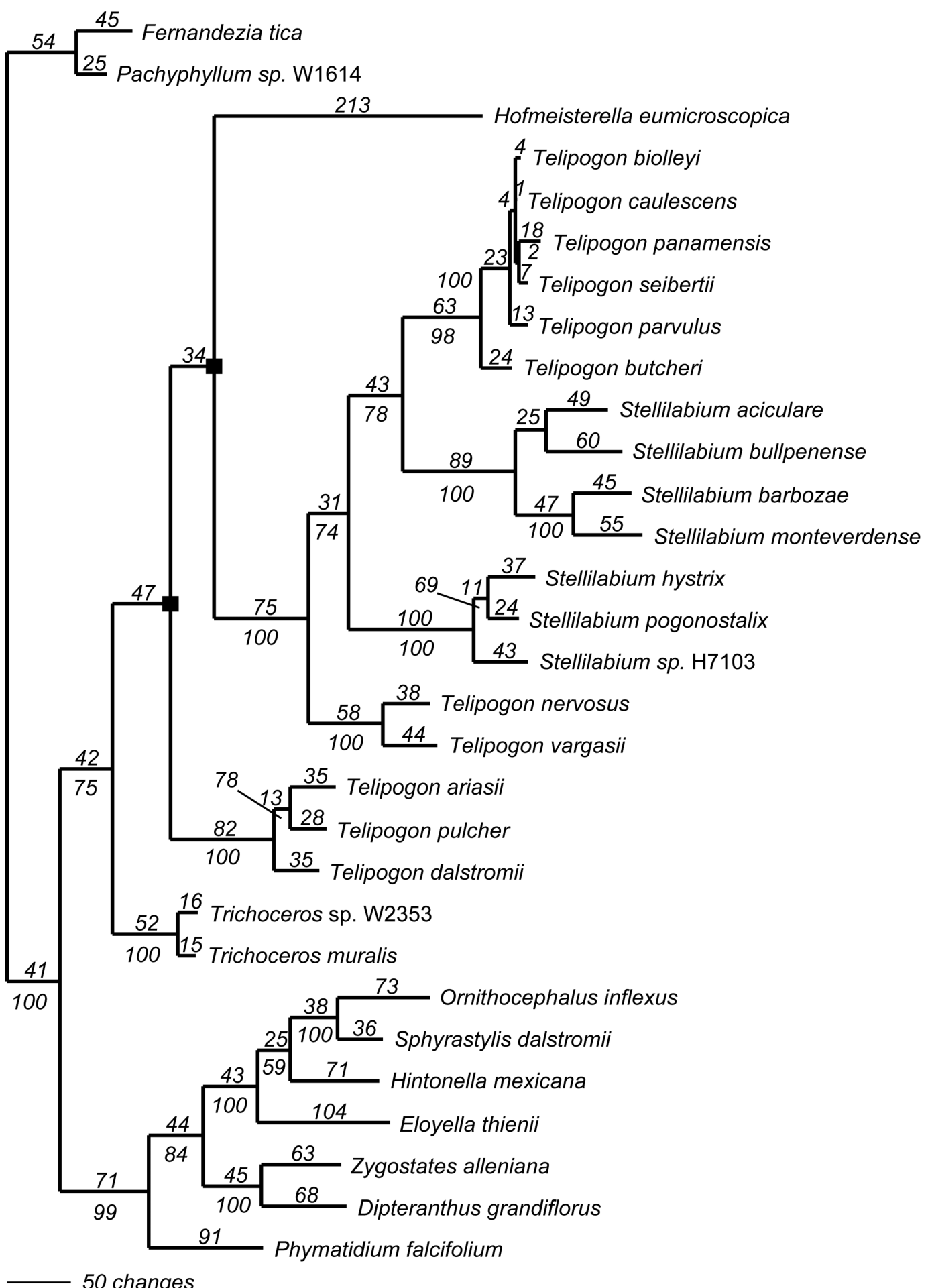

Fig. 1. One of eight trees for the limited ITS only analysis, with branch lengths (ACCTRAN optimization) above lines, bootstrap values below lines. Nodes that collapse in the strict consensus tree are indicated with a small black square. 


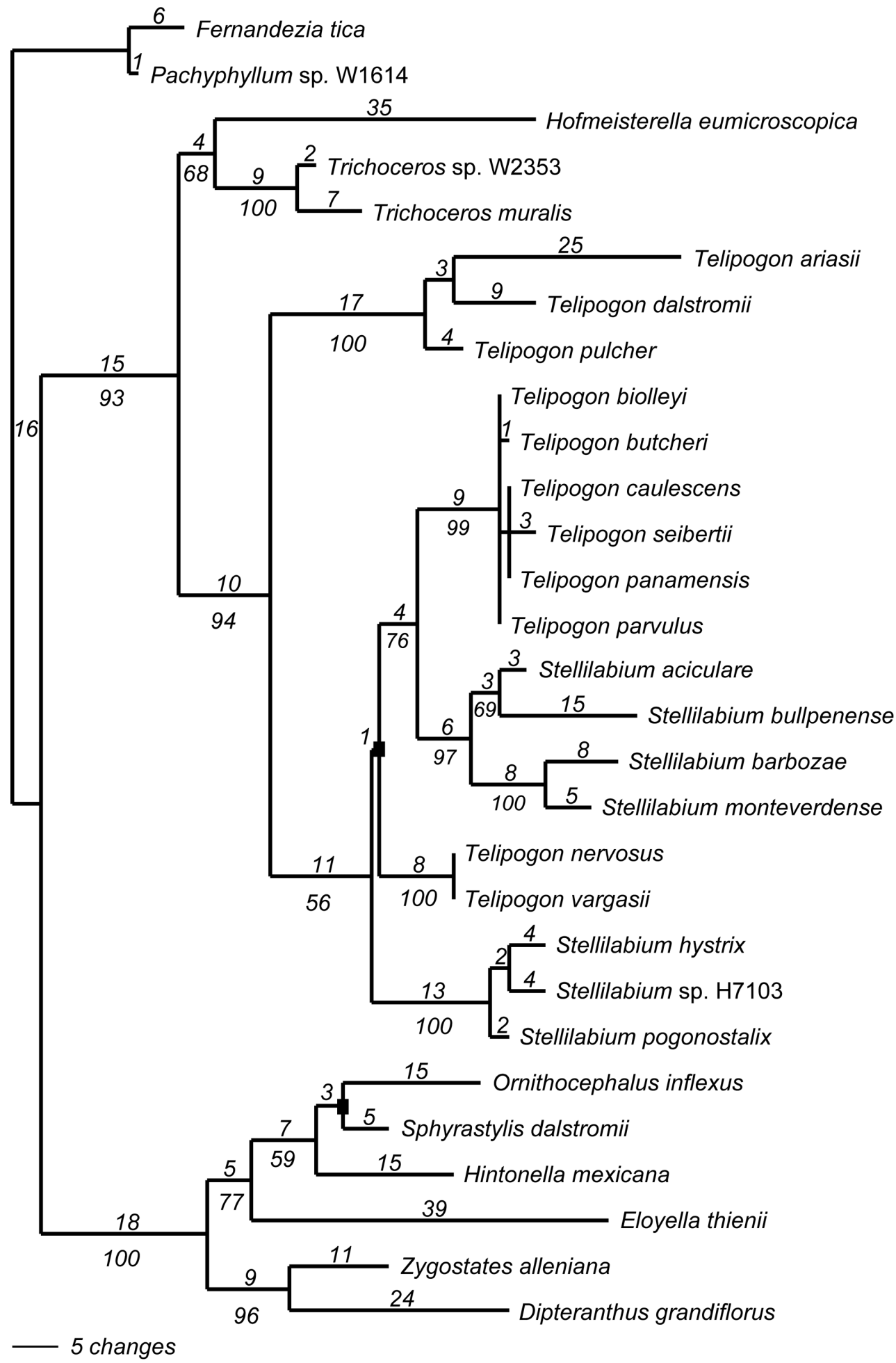

Fig. 2. One of 1458 trees for the limited $t r n L-F$ only analysis, with branch lengths (ACCTRAN optimization) above lines, bootstrap values below lines. Nodes that collapse in the strict consensus tree are indicated with a small black square. 


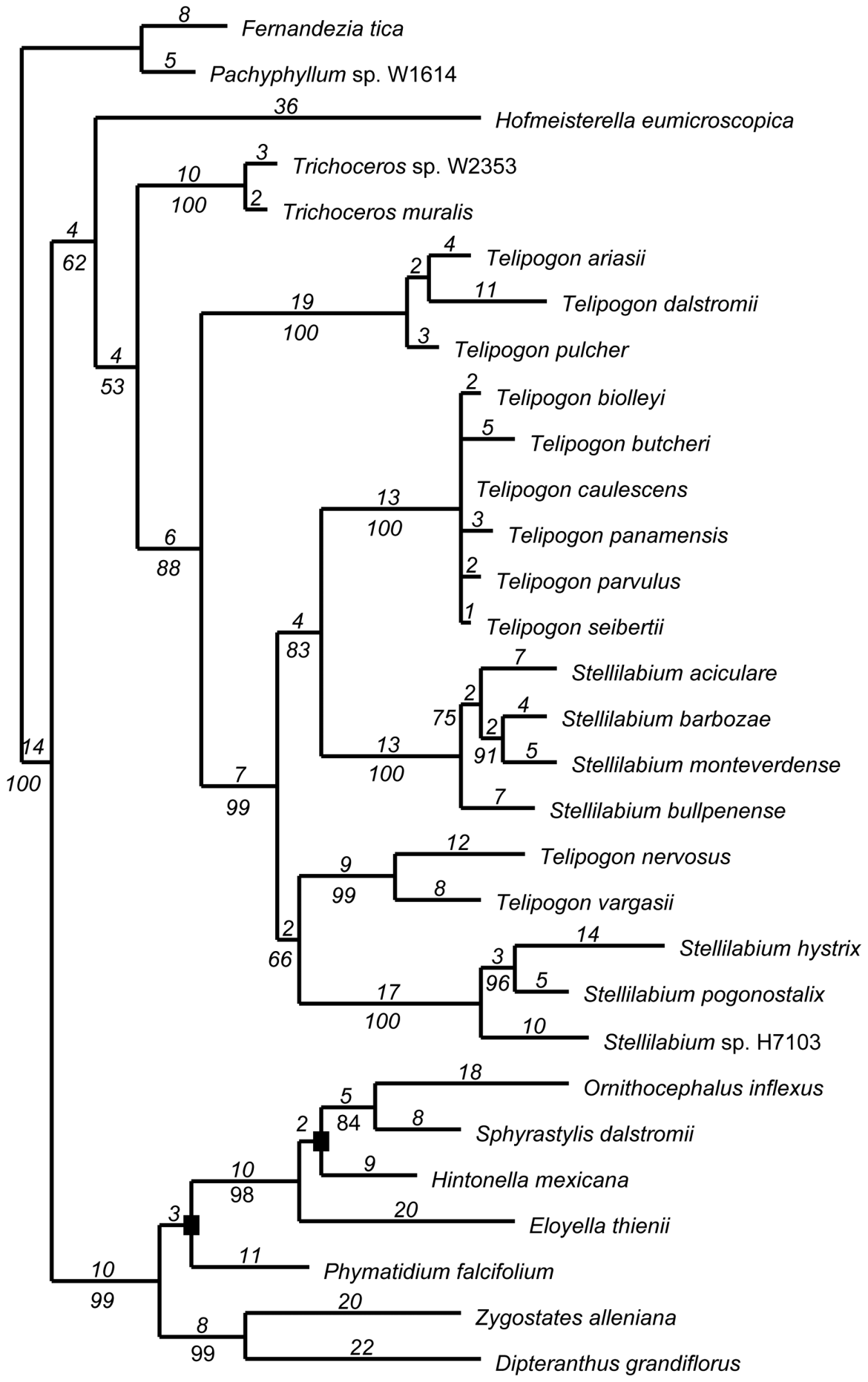

5 changes

Fig. 3. One of four trees for the limited matK only analysis, with branch lengths (ACCTRAN optimization) above lines, bootstrap values below lines. Nodes that collapse in the strict consensus tree are indicated with a small black square. 


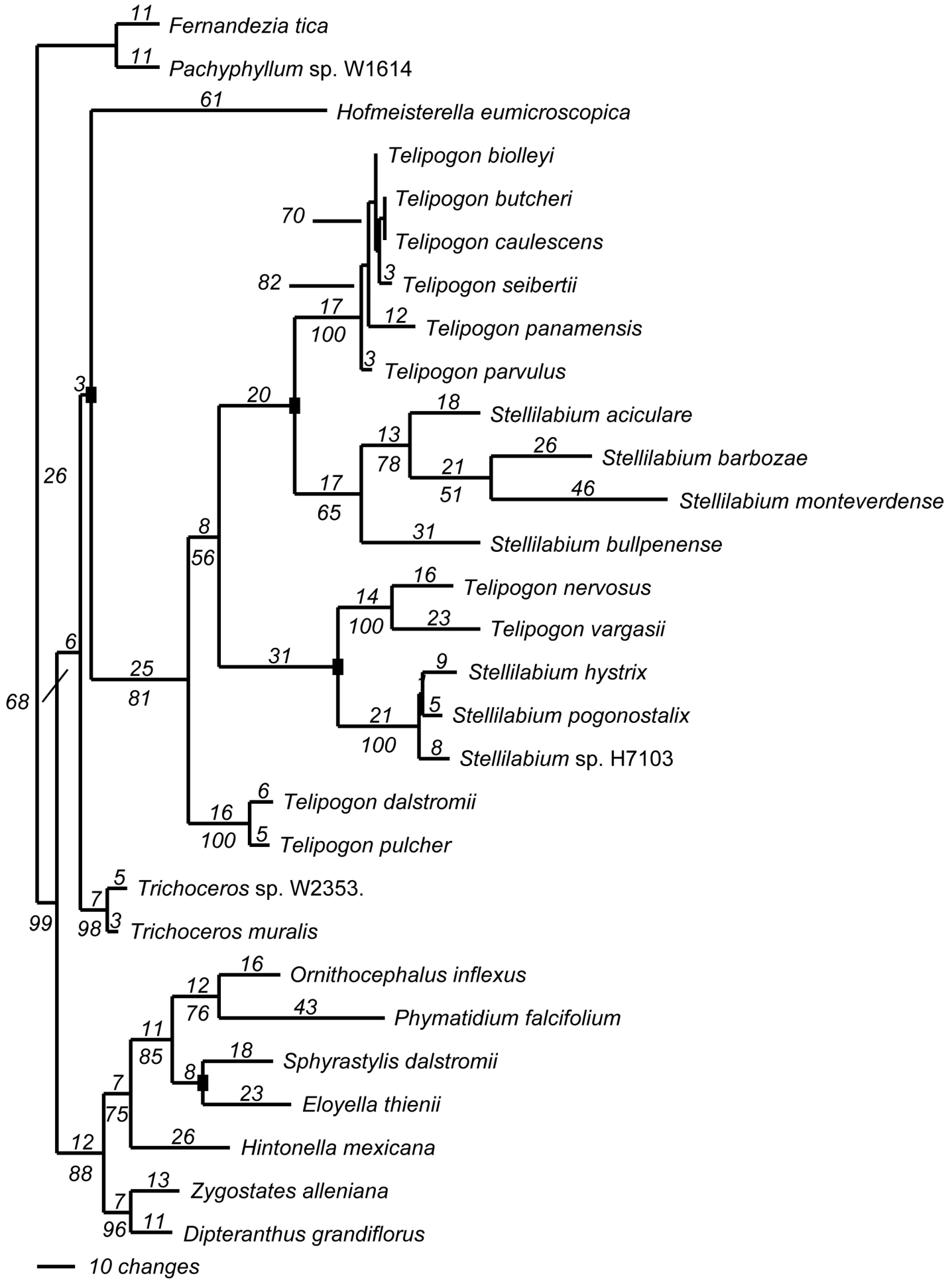

Fig. 4. One of three trees for the limited $a t p B-r b c L$ intergenic spacer region analysis, with branch lengths (ACCTRAN optimization) above lines, bootstrap values below lines. Nodes that collapse in the strict consensus tree are indicated with a small black square. 


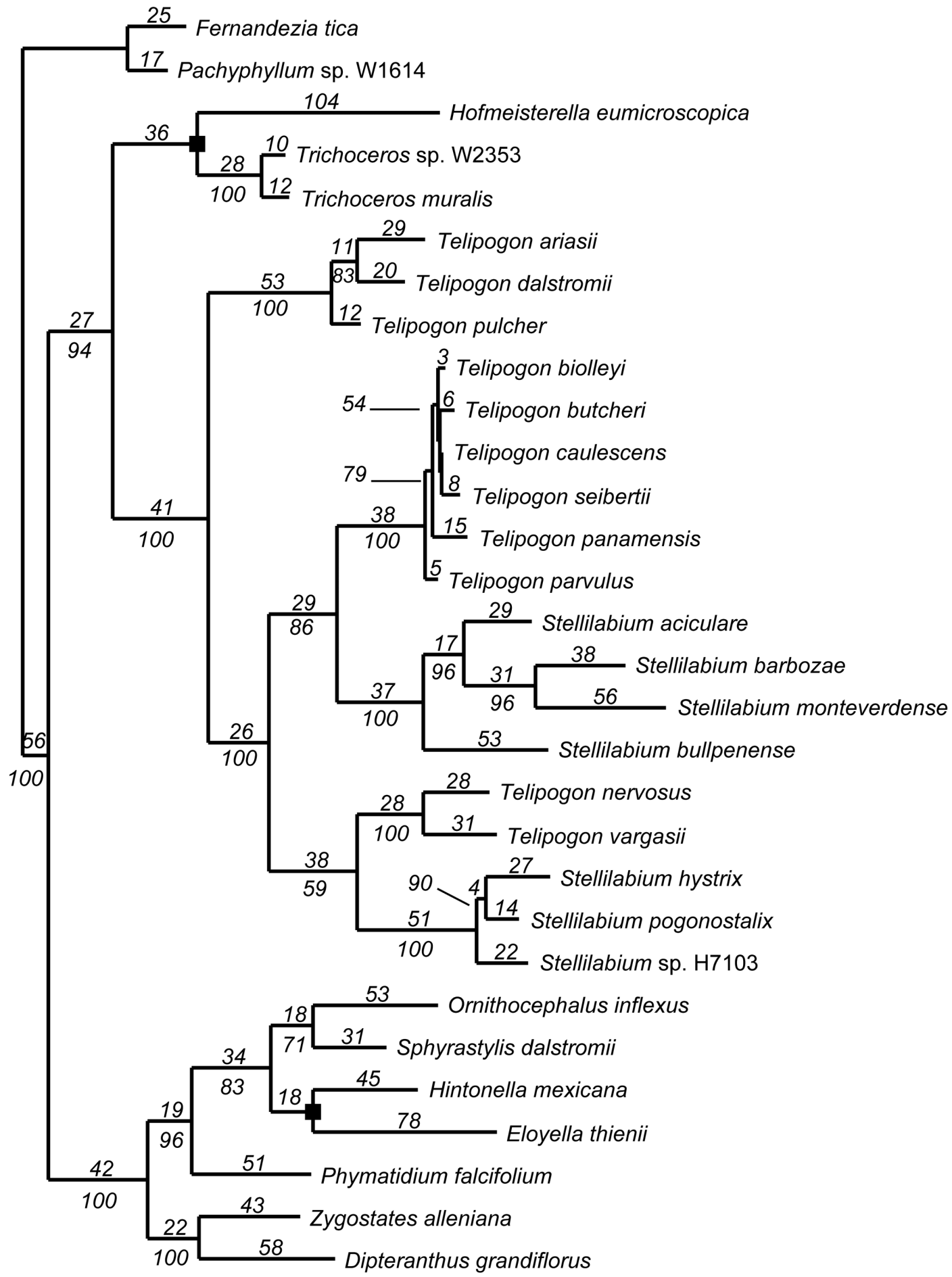

- 10 changes

Fig. 5. The one of four trees for the combined plastid data set for the limited analysis, with branch lengths (ACCTRAN optimization) above lines, bootstrap values below lines. Nodes that collapse in the strict consensus tree are indicated with a small black square. 

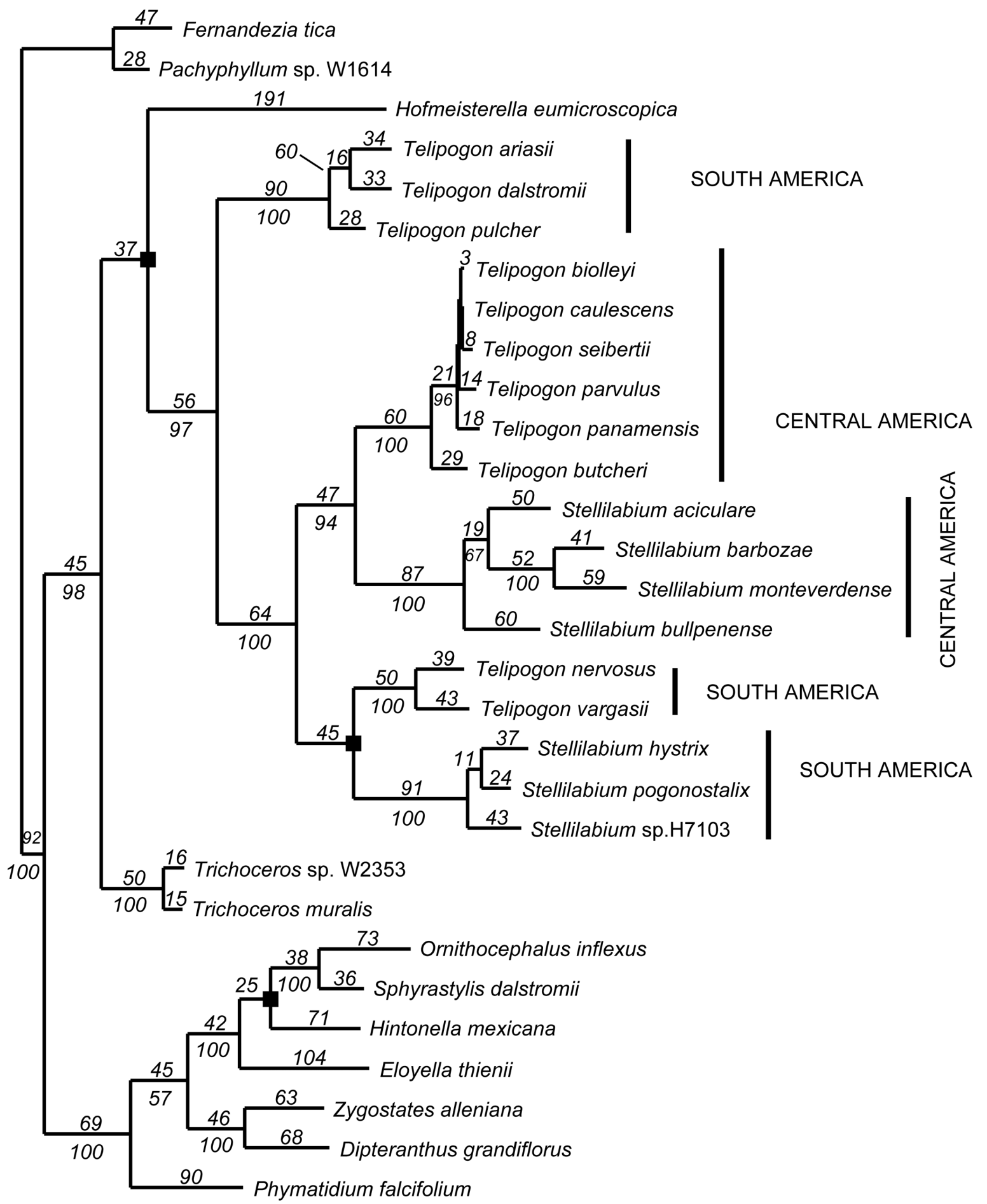

50 changes

Fig. 6. One of 30 trees for the combined ITS plus plastid data set analysis, with branch lengths (ACCTRAN optimization) above lines, bootstrap values below lines. Nodes that collapse in the strict consensus tree are indicated with a small black square. 


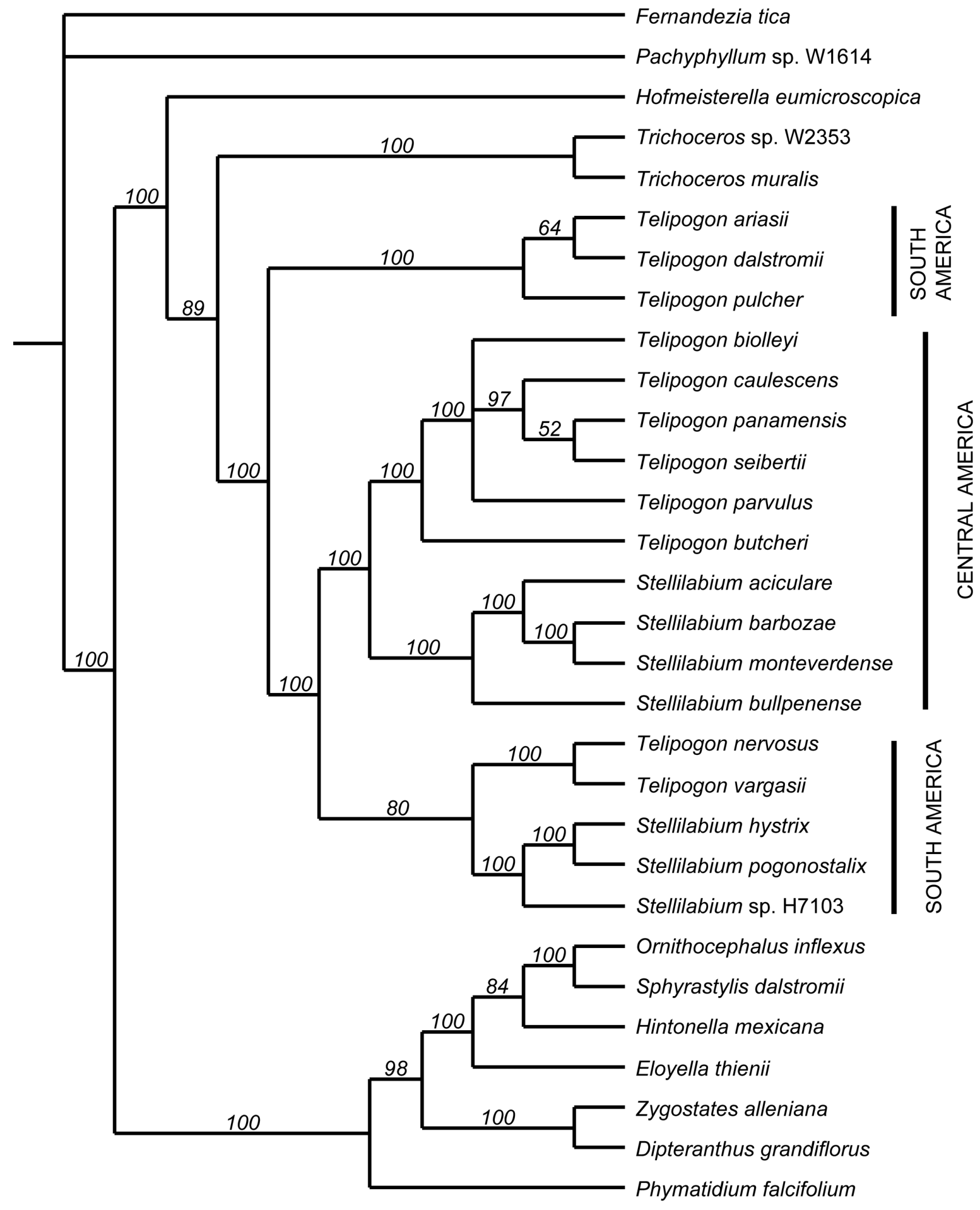

Fig. 7. The majority rule consensus tree for the Bayesian analysis of the combined ITS plus plastid data set with posterior probability values above lines. 


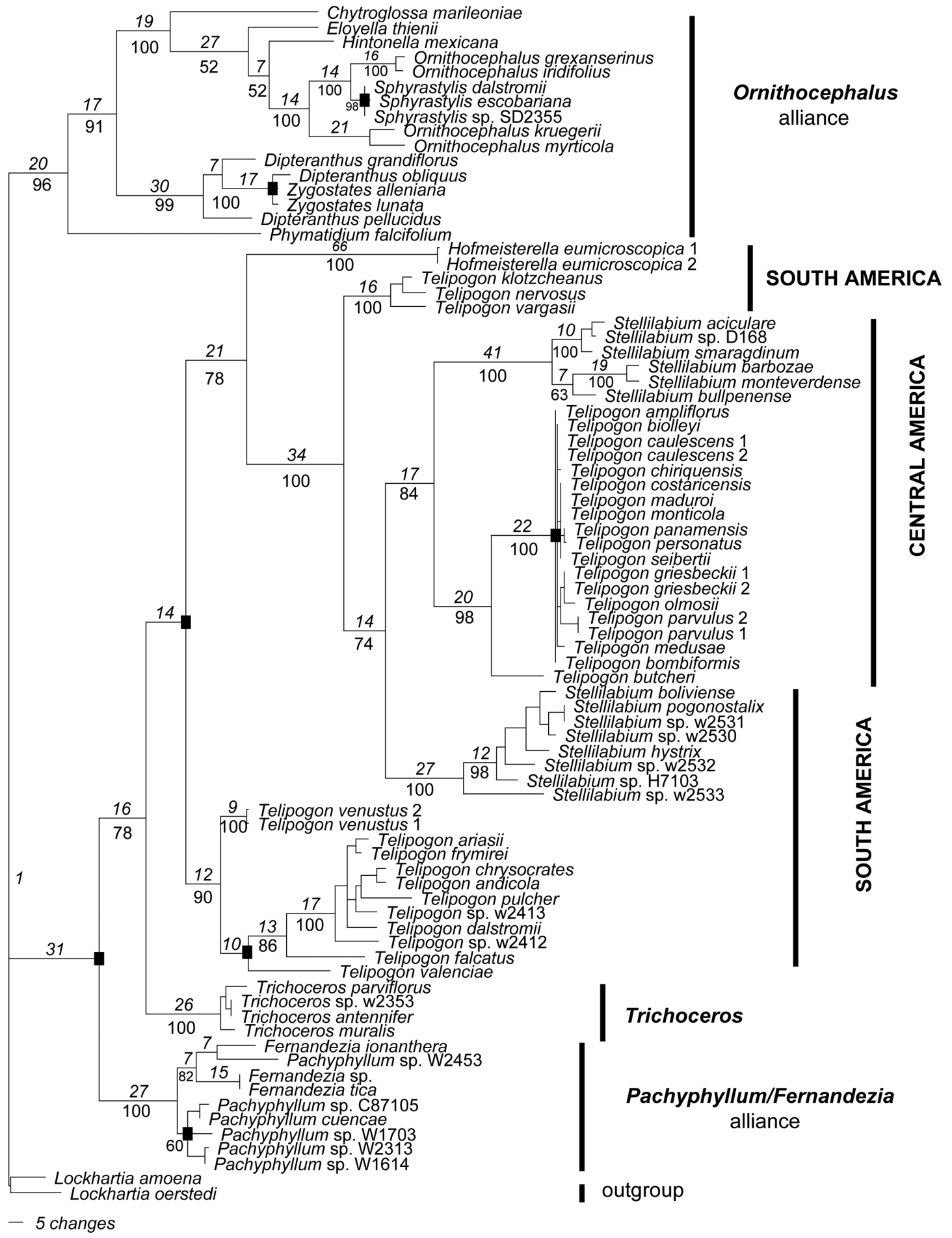

Fig. 8. One of 251 trees for ITS only for 81 taxa, with branch lengths (ACCTRAN optimization) above lines, bootstrap values below lines. Nodes that collapse in the strict consensus tree are indicated with a small black square. Branch lengths for terminal branches and for extremely short $(<7)$ branches omitted for clarity. See text for bootstrap values for the South American Stellilabium clade and the T. ariasii-T. venustus clade. 